\title{
Antimicrobial Activity of Oleanolic and Ursolic Acids: An Update
}

\author{
Jéssica A. Jesus, ${ }^{1,2}$ João Henrique G. Lago, ${ }^{2}$ Márcia D. Laurenti, ${ }^{1}$ \\ Eduardo S. Yamamoto, ${ }^{1}$ and Luiz Felipe D. Passero ${ }^{1}$ \\ ${ }^{1}$ Laboratório de Patologia de Moléstias Infecciosas, Departamento de Patologia, Faculdade de Medicina da Universidade de São Paulo, \\ Avenue Dr. Arnaldo 455, 06780-210 Cerqueira César, SP, Brazil \\ ${ }^{2}$ Instituto de Ciências Ambientais, Químicas e Farmacêuticas, Universidade Federal de São Paulo, Rua Professor Artur Riedel 275, \\ 09972-270 Diadema, SP, Brazil
}

Correspondence should be addressed to Luiz Felipe D. Passero; felipepassero@yahoo.com.br

Received 30 November 2014; Accepted 22 January 2015

Academic Editor: Ken Yasukawa

Copyright (C) 2015 Jéssica A. Jesus et al. This is an open access article distributed under the Creative Commons Attribution License, which permits unrestricted use, distribution, and reproduction in any medium, provided the original work is properly cited.

\begin{abstract}
Triterpenoids are the most representative group of phytochemicals, as they comprise more than 20,000 recognized molecules. These compounds are biosynthesized in plants via squalene cyclization, $\mathrm{C}_{30}$ hydrocarbon that is considered to be the precursor of all steroids. Due to their low hydrophilicity, triterpenes were considered to be inactive for a long period of time; however, evidence regarding their wide range of pharmacological activities is emerging, and elegant studies have highlighted these activities. Several triterpenic skeletons have been described, including some that have presented with pentacyclic features, such as oleanolic and ursolic acids. These compounds have displayed incontestable biological activity, such as antibacterial, antiviral, and antiprotozoal effects, which were not included in a single review until now. Thus, the present review investigates the potential use of these triterpenes against human pathogens, including their mechanisms of action, via in vivo studies, and the future perspectives about the use of compounds for human or even animal health are also discussed.
\end{abstract}

\section{Introduction}

The triterpenoids are the most representative group of phytochemicals; they comprise more than 20,000 recognized compounds and are biosynthesized in plants through squalene cyclization [1]. The triterpenes can be classified into groups based on their structural skeletons: cucurbitanes, cycloartanes, dammaranes, euphanes, friedelanes, holostanes, hopanes, isomalabaricanes, lanostanes, lupanes, oleananes, protostanes, tirucallanes, and ursanes, among others [2].

The diversity of triterpenes is highly associated with their broad range of pharmacological effects. In Asian countries, triterpenes are traditionally used as anti-inflammatory, analgesic, hepatoprotective, cardiotonic, and sedative agents [3]. Other studies have also demonstrated their antioxidant, antiallergic, antipruritic, antiangiogenic, and antimicrobial potential [4]. In addition, some studies have already demonstrated that several of these compounds exhibit anticancer potential, with high selectivity for cancer cells and the ability to induce apoptosis-related death in most cases [5-10]. Due to this specific action, several triterpenoids are currently being evaluated in phase I clinical trials [11].

Oleanolic acid (OA) and its isomer, ursolic acid (UA), are triterpenoid compounds that widely occur in nature in free acid form or as an aglycone precursor for triterpenoid saponins [12]. These triterpenoid acids frequently occur simultaneously because they share similar structural features. These compounds have also shown similar pharmacological activities, such as hepatoprotective, anti-inflammatory, antioxidant, and anticancer effects, which may be attributable to the different substructures in $\mathrm{A}, \mathrm{C}$, and $\mathrm{E}$ rings or other positions (Figure 1). 


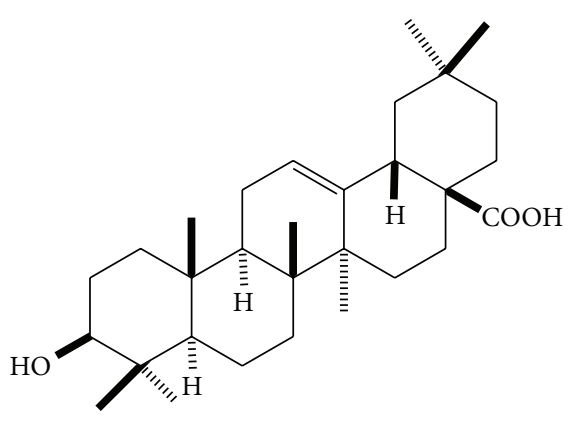

$\mathrm{OA}$

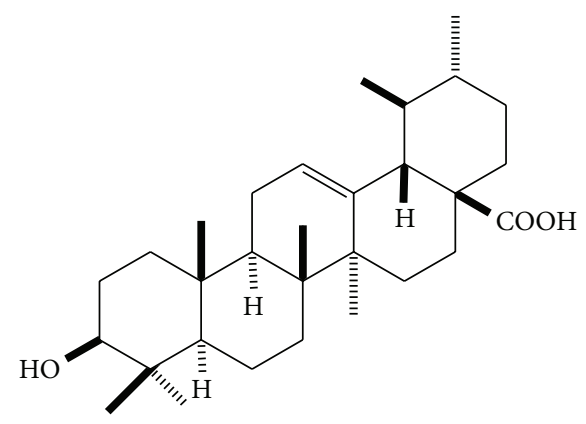

UA

FIgURE 1: Skeleton of oleanolic acid (OA) and ursolic acid (UA).

\section{Oleanolic Acid (OA)}

OA ( $3 \beta$-hydroxyolean-12-en-28-oic acid) is a pentacyclic triterpenoid with widespread occurrence throughout the plant kingdom. This compound and its derivatives possess several interesting pharmacological activities, such as antiinflammatory, antioxidant, anticancer, and hepatoprotective effects. OA was previously isolated from almost 2000 plant species [12-14], and the main source of this compound includes plants belonging to the Oleaceae family, such as Olea europaea (the olive) $[15,16]$. In plants, the biological roles of this compound are often associated with the formation of a barrier against water loss and pathogens [17]. Moreover, allelopathic properties have already been described for this compound [18]. Several medicinal plants produce and accumulate $\mathrm{OA}$ and its derivatives as their main metabolites, which could be directly associated with their biological activities, as shown in Table 1.

\section{Ursolic Acid (UA)}

UA ( $3 \beta$-hydroxyurs-12-en-28-oic acid) is a pentacyclic triterpenoid compound that shares a common cooccurrence with $\mathrm{OA}$ in several plant species; however, it features a more restricted distribution when compared to OA $[12,84]$. This compound has been found in large amounts in berries (such as cranberries) and mostly in the peel [85]. Similar to what is observed with OA, the biological role of UA in plants seems to be associated with protection against herbivores and pathogens [86]. The occurrence of UA and its derivatives as major metabolites in medicinal plants could be associated with their biological activities, as shown in Table 2 .

Many comprehensive reviews of OA and UA have been published and have covered different areas of interest, such as their isolation, structural determination, and pharmacological activities [12, 87-90].

In spite of the pharmacological effects that have already been demonstrated, different reports have shown that OA and UA exhibit antimycotic, antitumoral, antibacterial, antiviral, and antiparasitic properties [4, 9, 26, 91-95], suggesting that these compounds are important classes of prototypical natural antibiotic molecules. This review aims to summarize the information regarding the microbiocidal activities of both
OA and UA, highlighting the importance of these compounds as leading molecules with pharmacological and medical importance in the development of new drugs.

\section{Microbicidal Effects of Oleanolic and Ursolic Acids}

4.1. Antibacterial Properties of Oleanolic and Ursolic Acids. The antibacterial properties of OA and UA were assayed against different bacterial species, and the obtained results suggested the importance of these compounds as antibiotic drugs.

One of the first studies that aimed to evaluate the possible effect of OA and UA against bacteria was developed by Kozai et al. [96]. In this work, it was demonstrated that both of these triterpenes inhibited the synthesis of insoluble glucan, catalyzed by crude glucosyltransferase (GTase) from cariogenic Streptococcus mutans. Recently, the potential of UA against $S$. mutans and $S$. sobrinus was reinforced with a minimum inhibitory concentration (MIC) $)_{50}$ of $2.0 \mu \mathrm{g} / \mathrm{mL}$ [97], indicating that these compounds can inhibit caries in teeth.

When used against Mycobacterium tuberculosis, which is a bacterium that affects around one-third of the human population and represents the infection that causes the most deaths worldwide, it was found that OA isolated from Lantana hispida was also effective at displaying a MIC value of $25 \mu \mathrm{g} / \mathrm{mL}$ [49]. In addition, a MIC of $50 \mu \mathrm{g} / \mathrm{mL}$ was reported when OA was used against $M$. tuberculosis streptomycin-, isoniazid-, rifampin-, and ethambutol-resistant strains. Similar to OA, UA purified from Chamaedorea tepejilote leaves was capable of eliminating M. tuberculosis at $100 \mu \mathrm{g} / \mathrm{mL}$ [98], suggesting that there is a potential for both compounds to kill this pathogen.

The diversity of the antibacterial properties of OA and UA has also been illustrated against other human bacterial pathogens, such as $S$. pneumonia (MIC of $16 \mu \mathrm{g} / \mathrm{mL}$ ), methicillin-sensitive and methicillin-resistant Staphylococcus aureus (MIC of $8 \mu \mathrm{g} / \mathrm{mL}$ and $64 \mu \mathrm{g} / \mathrm{mL}$, resp.) [129], Bacillus subtilis (MIC of $8 \mu \mathrm{g} / \mathrm{mL}$ ), B. cereus, Enterococcus faecalis (MIC of 6.25-8.00 $\mu \mathrm{g} / \mathrm{mL}$ ), E. faecium (MIC of $8 \mu \mathrm{g} / \mathrm{mL}$ ), and Pseudomonas aeruginosa (MIC of $256 \mu \mathrm{g} / \mathrm{mL}$ ) [130-132]. 
TABLE 1: Oleanolic acid's (OA) derivatives and their biological activities.

\begin{tabular}{|c|c|c|}
\hline Plant species (family) & Biological activity & Reference \\
\hline \multirow{3}{*}{$\begin{array}{l}\text { Aceriphyllum rossii } \\
\text { (Saxifragaceae) }\end{array}$} & Cytotoxic & {$[19]$} \\
\hline & Anticomplement activity & {$[20]$} \\
\hline & & {$[21]$} \\
\hline $\begin{array}{l}\text { Actinidia chinensis } \\
\text { (Actinidiaceae) }\end{array}$ & Hepatoprotection & {$[22]$} \\
\hline $\begin{array}{l}\text { Aralia chinensis } \\
\text { (Araliaceae) }\end{array}$ & Hepatoprotection & {$[23,24]$} \\
\hline $\begin{array}{l}\text { Astilbe chinensis } \\
\text { (Saxifragaceae) }\end{array}$ & Cytotoxic & {$[25]$} \\
\hline \multirow{2}{*}{$\begin{array}{l}\text { Baccharis uncinella } \\
\text { (Asteraceae) }\end{array}$} & \multirow[t]{2}{*}{ Antileishmanial } & {$[26]$} \\
\hline & & {$[27]$} \\
\hline $\begin{array}{l}\text { Baeckea gunniana } \\
\text { (Myrtaceae) }\end{array}$ & Inhibition of $\beta$-DNA polymerase & {$[28]$} \\
\hline $\begin{array}{l}\text { Beta vulgaris } \\
\text { (Chenopodiaceae) }\end{array}$ & Hepatoprotection & {$[29,30]$} \\
\hline $\begin{array}{l}\text { Betula ermanii } \\
\text { (Betulaceae) }\end{array}$ & Antitumor & {$[31]$} \\
\hline $\begin{array}{l}\text { Calendula officinalis } \\
\text { (Compositae) }\end{array}$ & Antifungal activity & {$[32]$} \\
\hline $\begin{array}{l}\text { Chrysosplenium carnosum } \\
\text { (Saxifragaceae) }\end{array}$ & Cytotoxic & {$[33]$} \\
\hline $\begin{array}{l}\text { Diospyros kaki } \\
\text { (Ebenaceae) }\end{array}$ & Inhibition of tyrosine phosphatase & {$[34]$} \\
\hline $\begin{array}{l}\text { Dysoxylum hainanense } \\
\text { (Meliaceae) }\end{array}$ & Antibacterial & {$[35]$} \\
\hline $\begin{array}{l}\text { Eclipta prostrata } \\
\text { (Asteraceae) }\end{array}$ & Antifibrotic activity & {$[36]$} \\
\hline $\begin{array}{l}\text { Embelia schimperi } \\
\text { (Myrsinaceae) }\end{array}$ & Antibacterial & {$[37]$} \\
\hline $\begin{array}{l}\text { Eugenia jambolana } \\
\text { (Myrtaceae) }\end{array}$ & $\begin{array}{l}\text { Inhibition of lipid peroxidation and protection against } \\
\text { adriamycin toxicity; antifertility activity }\end{array}$ & {$[38-40]$} \\
\hline $\begin{array}{l}\text { Fagus hayatae } \\
\text { (Fagaceae) }\end{array}$ & $\alpha$-glucosidase inhibition & {$[41]$} \\
\hline $\begin{array}{l}\text { Fatsia polycarpa } \\
\text { (Araliaceae) }\end{array}$ & Cytotoxic, antihepatitis B virus (HBV), and antibacterial & {$[42]$} \\
\hline $\begin{array}{l}\text { Ganoderma lucidum } \\
\text { (Labiatae) }\end{array}$ & Anticariogenic activity & {$[43]$} \\
\hline $\begin{array}{l}\text { Glechoma hederacea } \\
\text { (Labiatae) }\end{array}$ & $\begin{array}{l}\text { Inhibition of azoxymethane-induced carcinogenesis in rats; } \\
\text { Antitumor promotion }\end{array}$ & {$[44-46]$} \\
\hline $\begin{array}{l}\text { Ilex kudincha } \\
\text { (Aquifoliaceae) }\end{array}$ & Inhibition of acyl CoA cholesteryl acyl transferase & {$[47]$} \\
\hline $\begin{array}{l}\text { Junellia aspera } \\
\text { (Verbenaceae) }\end{array}$ & Cytotoxic & {$[48]$} \\
\hline $\begin{array}{l}\text { Lantana hispida } \\
\text { Verbenaceae) }\end{array}$ & Antimycobacterial & {$[49]$} \\
\hline $\begin{array}{l}\text { Liquidambar formosana } \\
\text { (Altingiaceae) }\end{array}$ & Inhibition of NFAT transcription factor & {$[50]$} \\
\hline $\begin{array}{l}\text { Ligustrum lucidum } \\
\text { (Oleaceae) }\end{array}$ & $\begin{array}{l}\text { Anti-inflammatory; antihyperglycemic; inhibition of } \\
\text { mutagenicity by B(a)P }\end{array}$ & {$[51-54]$} \\
\hline $\begin{array}{l}\text { Luffa cylindrica } \\
\text { (Cucurbitaceae) }\end{array}$ & $\begin{array}{l}\text { Anti-inflammatory and inhibition of C3-convertase of the } \\
\text { complement pathway }\end{array}$ & {$[55,56]$} \\
\hline $\begin{array}{l}\text { Lysimachia heterogenea } \\
\text { (Primulaceae) }\end{array}$ & Cytotoxic & {$[57]$} \\
\hline
\end{tabular}


TABle 1: Continued.

\begin{tabular}{|c|c|c|}
\hline Plant species (family) & Biological activity & Reference \\
\hline $\begin{array}{l}\text { Lysimachia parvifolia } \\
\text { (Primulaceae) }\end{array}$ & Cytotoxic & {$[58]$} \\
\hline $\begin{array}{l}\text { Nardophyllum bryoides } \\
\text { (Asteraceae) }\end{array}$ & Cytotoxic & {$[59]$} \\
\hline $\begin{array}{l}\text { Microtropis japonica } \\
\text { (Celastraceae) }\end{array}$ & Cytotoxic & {$[60]$} \\
\hline $\begin{array}{l}\text { Nigella glandulifera } \\
\text { (Ranunculaceae) }\end{array}$ & Cytotoxic & {$[61]$} \\
\hline $\begin{array}{l}\text { Oleandra neriifolia } \\
\text { (Araliaceae) }\end{array}$ & Anti-inflammatory & {$[62]$} \\
\hline $\begin{array}{l}\text { Panax ginseng } \\
\text { (Araliaceae) }\end{array}$ & Hepatoprotection & {$[63]$} \\
\hline \multirow{2}{*}{$\begin{array}{l}\text { Panax stipuleanatus } \\
\text { (Araliaceae) }\end{array}$} & Anticancer & {$[64,65]$} \\
\hline & Inhibition of NF- $\kappa \mathrm{B}$ & \\
\hline $\begin{array}{l}\text { Phyllanthus flexuosus } \\
\text { (Euphorbiaceae) }\end{array}$ & Inhibition of DNA topoisomerases I and II & {$[66]$} \\
\hline $\begin{array}{l}\text { Platycodon grandiflorum } \\
\text { (Campanulaceae) }\end{array}$ & Antiproliferative & {$[67]$} \\
\hline \multirow{2}{*}{$\begin{array}{l}\text { Rosa laevigata } \\
\text { (Rosaceae) }\end{array}$} & Anti-inflammatory & {$[68,69]$} \\
\hline & $\mathrm{NF}-\kappa \mathrm{B}$ transcriptional activity & \\
\hline $\begin{array}{l}\text { Sapindus mukorossi } \\
\text { (Sapindaceae) }\end{array}$ & Anti-inflammatory & {$[70]$} \\
\hline $\begin{array}{l}\text { Siphonodon celastrineus } \\
\text { (Celastraceae) }\end{array}$ & Cytotoxic & {$[71,72]$} \\
\hline $\begin{array}{l}\text { Swertia mileensis } \\
\text { (Gentianaceae) }\end{array}$ & Hepatoprotection & {$[73-75]$} \\
\hline $\begin{array}{l}\text { Swertia japonica } \\
\text { (Gentianaceae) }\end{array}$ & Hepatoprotection & {$[76]$} \\
\hline $\begin{array}{l}\text { Terminalia arjuna } \\
\text { (Combretaceae) }\end{array}$ & Cardioprotection & {$[77]$} \\
\hline $\begin{array}{l}\text { Terminalia chebula } \\
\text { (Combretaceae) }\end{array}$ & Cytotoxic & {$[78]$} \\
\hline $\begin{array}{l}\text { Tetrapanax papyriferum } \\
\text { (Araliaceae) }\end{array}$ & Hepatoprotection & {$[79]$} \\
\hline $\begin{array}{l}\text { Tinospora sagittata } \\
\text { (Menispermaceae) }\end{array}$ & Antihyperglycemic & {$[80]$} \\
\hline $\begin{array}{l}\text { Uncaria laevigata } \\
\text { (Rubiaceae) }\end{array}$ & Inhibition of $\alpha$-glucosidase & {$[81]$} \\
\hline $\begin{array}{l}\text { Uncaria sessilifructus } \\
\text { (Rubiaceae) }\end{array}$ & $\begin{array}{l}\text { Inhibition of activities against LPS-induced nitric oxide } \\
\text { production in RAW264.7 macrophages }\end{array}$ & {$[82]$} \\
\hline $\begin{array}{l}\text { Viburnum chingii } \\
\text { (Adoxaceae) }\end{array}$ & Cytotoxic & {$[83]$} \\
\hline
\end{tabular}

Although few works have examined the mode of action of these triterpenes, studies conducted with E. coli demonstrated that OA can moderately affect the efflux of pumps, which could directly interfere with the viability of this species [133]. Other mechanisms of action of OA can be associated with the induction of a stress response. Grudniak et al. [134] observed that $E$. coli treated with OA altered the synthesis of DnaK, thus inducing the heat-shock response in this species. Kurek et al. [135] also verified that both OA and UA inhibited peptidoglycan turnover in Listeria monocytogenes, affecting the amount of muropeptides and, ultimately, the cellular wall of bacteria, suggesting that this biochemical pathway can be a target for both triterpenes.

Taken together, these works suggest that OA and UA possess a broad range of antibacterial activity, mainly against gram-positive bacteria. In addition, all of these works have alerted us to the important classes of prototype drugs that can be derived from these triterpenes, including the development of drugs that can be used against infections caused by drugresistant bacteria species. 
TABLE 2: Ursolic acid's (UA) derivatives and their biological activities.

\begin{tabular}{|c|c|c|}
\hline Plant species (family) & Biological activity & Reference \\
\hline $\begin{array}{l}\text { Actinidia chinensis } \\
\text { (Actinidiaceae) }\end{array}$ & Hepatoprotective & {$[99]$} \\
\hline $\begin{array}{l}\text { Baeckea gunniana } \\
\text { (Myrtaceae) }\end{array}$ & Inhibition of $\beta$-DNA polymerase & {$[28]$} \\
\hline $\begin{array}{l}\text { Callana vulgaris } \\
\text { (Ericaceae) }\end{array}$ & Inhibition of lipoxygenase and cyclooxygenase in HL-60 leukemic cells & {$[100,101]$} \\
\hline $\begin{array}{l}\text { Centella asiatica } \\
\text { (Mackinlayaceae) }\end{array}$ & Inhibition of NO & {$[102]$} \\
\hline $\begin{array}{l}\text { Emmenopterys henryi } \\
\text { (Rubiaceae) }\end{array}$ & Cytotoxic & {$[103]$} \\
\hline $\begin{array}{l}\text { Eribotrya japonica } \\
\text { (Rosaceae) }\end{array}$ & Inhibition of mutagenesis in bacteria & {$[104]$} \\
\hline $\begin{array}{l}\text { Eucalyptus hybrid } \\
\text { (Myrtaceae) }\end{array}$ & Hepatoprotection & {$[105]$} \\
\hline $\begin{array}{l}\text { Eucalyptus loxophleba } \\
\text { (Myrtaceae) }\end{array}$ & Antileishmanial & {$[106]$} \\
\hline $\begin{array}{l}\text { Fragaria ananassa } \\
\text { (Rosaceae) }\end{array}$ & Cytotoxic & {$[107]$} \\
\hline $\begin{array}{l}\text { Gentiana aristata } \\
\text { (Gentianacea) }\end{array}$ & Cytotoxic & {$[108]$} \\
\hline $\begin{array}{l}\text { Glechoma hederacea } \\
\text { (Labiatae) }\end{array}$ & Antitumor promotion & {$[46]$} \\
\hline $\begin{array}{l}\text { Ilex cornuta } \\
\text { (Aquifoliaceae) }\end{array}$ & Cytotoxic & {$[109]$} \\
\hline $\begin{array}{l}\text { Leonurus cardiaca } \\
\text { (Lamiaceae) }\end{array}$ & Anti-inflammatory & {$[110]$} \\
\hline $\begin{array}{l}\text { Melaleuca leucadendron } \\
\text { (Myrtaceae) }\end{array}$ & Inhibition of histamine release & {$[111]$} \\
\hline $\begin{array}{l}\text { Microtropis japonica } \\
\text { (Celastraceae) }\end{array}$ & Cytotoxic & {$[60]$} \\
\hline $\begin{array}{l}\text { Mulgedium tataricum } \\
\text { (Asteraceae) }\end{array}$ & Cytotoxic/antibacterial & {$[112]$} \\
\hline $\begin{array}{l}\text { Nauclea officinalis } \\
\text { (Rubiaceae) }\end{array}$ & Inhibition of NO production & {$[113]$} \\
\hline $\begin{array}{l}\text { Nardophyllum bryoides } \\
\text { (Asteraceae) }\end{array}$ & Cytotoxic & {$[59]$} \\
\hline $\begin{array}{l}\text { Ocimum sanctum } \\
\text { (Labiatae) }\end{array}$ & Inhibition of lipid peroxidation and protection against adriamycin toxicity & {$[38,39]$} \\
\hline $\begin{array}{l}\text { Petasites tricholobus } \\
\text { (Asteraceae) }\end{array}$ & Antibacterial & {$[114]$} \\
\hline $\begin{array}{l}\text { Potentilla fulgens } \\
\text { (Rosaceae) }\end{array}$ & Antioxidant & {$[115]$} \\
\hline $\begin{array}{l}\text { Pyrola rotundifolia } \\
\text { (Pyrolaceae) }\end{array}$ & Anti-inflammatory & {$[116]$} \\
\hline $\begin{array}{l}\text { Psychotria serpens } \\
\text { (Rubiaceae) }\end{array}$ & Cytotoxic to leukemia cells & {$[117]$} \\
\hline $\begin{array}{l}\text { Rhododendron brachycarpum } \\
\text { (Ericaceae) }\end{array}$ & Inhibition of PTP1B & {$[118]$} \\
\hline $\begin{array}{l}\text { Rosa laevigata } \\
\text { (Rosaceae) }\end{array}$ & Anti-inflammatory & {$[68]$} \\
\hline $\begin{array}{l}\text { Rosmarinus officinalis } \\
\text { (Labiatae) }\end{array}$ & $\begin{array}{l}\text { Antimicrobial activity; inhibition of mouse skin tumorigenesis; } \\
\text { anti-inflammatory }\end{array}$ & {$[85,119]$} \\
\hline
\end{tabular}


TABLE 2: Continued.

\begin{tabular}{|c|c|c|}
\hline Plant species (family) & Biological activity & Reference \\
\hline $\begin{array}{l}\text { Salvia miltiorrhiza } \\
\text { (Lamiaceae) }\end{array}$ & Inhibition of atherosclerosis & {$[120]$} \\
\hline $\begin{array}{l}\text { Saprosma merrillii } \\
\text { (Rubiaceae) }\end{array}$ & Cytotoxic & {$[121]$} \\
\hline $\begin{array}{l}\text { Siphonodon celastrineus } \\
\text { (Celastraceae) }\end{array}$ & Cytotoxic & {$[71]$} \\
\hline $\begin{array}{l}\text { Solanum incanum } \\
\text { (Solanaceae) }\end{array}$ & Hepatoprotection & {$[122]$} \\
\hline $\begin{array}{l}\text { Symplocos lancifolia } \\
\text { (Symplocaceae) }\end{array}$ & Antibacterial & {$[123]$} \\
\hline $\begin{array}{l}\text { Teucrium viscidum } \\
\text { (Lamiaceae) }\end{array}$ & Inhibition of activities against $11 \beta$-HSD1 & {$[124]$} \\
\hline $\begin{array}{l}\text { Triplerospermum taiwanense } \\
\text { (Gentianaceae) }\end{array}$ & Hepatoprotection & {$[125]$} \\
\hline $\begin{array}{l}\text { Uncaria laevigata } \\
\text { (Rubiaceae) }\end{array}$ & Inhibition of $\alpha$-glucosidase & {$[81]$} \\
\hline $\begin{array}{l}\text { Uncaria sessilifructus } \\
\text { (Rubiaceae) }\end{array}$ & $\begin{array}{l}\text { Inhibition of activities against LPS-induced nitric oxide production in } \\
\text { RAW264.7 macrophages }\end{array}$ & {$[82]$} \\
\hline $\begin{array}{l}\text { Vladimiria muliensis } \\
\text { (Asteraceae) }\end{array}$ & Antimicrobial & {$[126]$} \\
\hline \multirow{2}{*}{$\begin{array}{l}\text { Weigela subsessilis } \\
\text { (Caprifoliaceae) }\end{array}$} & Diabetes treatment & {$[127]$} \\
\hline & Anticomplementary & {$[128]$} \\
\hline
\end{tabular}

4.2. Antiviral Properties of Oleanolic and Ursolic Acids. The antiviral properties of OA and UA have been studied since the 1990s, specifically those used against human immunodeficiency virus (HIV) and the hepatitis virus. HIV belongs to the Retroviridae family and the genus, Lentivirus, which produces characteristically slow and progressive infection [136]. One of the first works [137] dealing with this subject showed that UA purified from Cynomorium songaricum (Cynomoriaceae) inhibited HIV-1 protease in a dose-dependent manner (inhibitory concentration $[\mathrm{IC}]_{50}$ of $8 \mu \mathrm{g} / \mathrm{mL}$ ). OA and its derivatives were also capable of inhibiting HIV-1 protease, with an $\mathrm{IC}_{50}$ of $4-20 \mu \mathrm{g} / \mathrm{mL}$ [138]. The inhibition of this enzyme produces immature and noninfectious virions and molecules, consequently blocking the life cycle of HIV [139]; this will ultimately improve the patient's quality of life. In addition, ex vivo experiments showed that peripheral blood mononuclear cells (PBMC) from $\mathrm{HIV}$-infected patients, which were incubated with different doses of OA, presented significant reduction of viral replication, which was comparable with the drug, azidothymidine (AZT). Similar results were found when PBMC from healthy donors were infected with $\mathrm{HIV}-1$, yielding an effective concentration $(\mathrm{EC})_{50}$ of $22.7 \mu \mathrm{M}$ and $24.6 \mu \mathrm{M}$, respectively [140]. Moreover, [141] demonstrated that OA was capable of eliminating, with high selectivity, HIV (therapeutic index [TI] ratio of 12.8) when compared to the H9 cell lineage; however, the AZT drug presented with the highest TI, which was 41.667.

The potential of OA and UA was also determined against hepatitis $B$ and $\mathrm{C}$ viruses ( $\mathrm{HBV}$ and $\mathrm{HCV}$, resp.). These viruses are of serious concern for human populations, since approximately 500 million people are chronically infected with one or both viruses, resulting in fibrosis and cirrhosis of the liver, and ultimately leading to the development of hepatocellular carcinoma $[142,143]$. Although vaccines and therapeutic strategies against these viruses already exist, new drug prototypes are under development, such as OA and UA. In this regard, it was demonstrated that UA primarily decreased the migratory process and matrix metalloproteinase- 3 secretion in HBV X protein-transactivated cell lineages. In addition, UA-treated cells were more sensitive to transforming growth factor- (TGF-) $\beta$-mediated apoptosis than were the control cells. In vivo experiments showed that $\mathrm{HBV}$-induced tumors were significantly lower in UA-treated animals when compared to controls [144]. These interesting studies showed that UA could block the pathological effects of HBV in cell lineages, suggesting that new classes of antiviral drugs could be developed using UA. In contrast, OA isolated from Ligustri lucidi seems to be very effective at eliminating intracellular $\mathrm{HCV}$ with an $\mathrm{IC}_{50}$ of $5.5 \mu \mathrm{g} / \mathrm{mL}$ and a high selectivity index (SI) of 30.8. Otherwise, the $\mathrm{IC}_{50}$ found for UA activity was higher than that determined for OA $\left(\mathrm{IC}_{50}\right.$ of $\left.33.8 \mu \mathrm{g} / \mathrm{mL}\right)$, and the latter featured a lower SI (6.7). In addition, one possible mechanism of action of OA was related to the suppression of the viral NS5B RdRp enzyme, which is a central enzyme responsible for HCV RNA replication [145].

UA and OA were also assayed against the proliferation of herpes viruses in host cells. Herpes simplex viruses (HSV) cause herpes labiles, herpes genitalis, keratitis, and encephalitis. The HSV infection caused by type- 1 and type- 2 viruses is mainly transmitted through close personal contact. The therapy that is used against the infection has severe side effects, and drug-resistant viruses have been detected 
[146], justifying the rationale to search for new drugs. In this regard, ethnomedicinal studies conducted in India showed that some plants used to treat skin problems, such as Mallotus peltatus and Achyranthes aspera [147, 148], produce appreciable amounts of UA and OA [149]. Considering that herpes infections affect the skin and mucosa, Bag et al. [146] and Mukherjee et al. [150] assayed crude extracts of, and active fractions derived from, M. peltatus and A. aspera, which contained UA and OA. The researchers found that both fractions presented with strong inhibitory activity against HSV-1 and HSV-2, which was comparable to the standard drug, Aciclovir. In addition, the OA-containing fraction from A. aspera triggered interleukin- (IL-) 12 production in treated peritoneal macrophages [150], which is an important cytokine that is responsible for activating the $\mathrm{CD} 4^{+} \mathrm{Th} 1$ cell population and for eliminating intracellular pathogens [151, 152].

These works indicate that $\mathrm{OA}$ and $\mathrm{UA}$ inhibit viral spreading in different host cell lineages with high levels of sensitivity and selectivity; this mainly depends upon the virus type and the host cell. In addition, the mechanism of action of both triterpenes was related to the control of virus replication and also to the immunomodulatory effect on the host cells, suggesting that new drugs can be developed from these structures.

4.3. The Antiprotozoal Properties of $\mathrm{OA}$ and UA. OA and UA also displayed appreciable antiparasitic effects against Plasmodium falciparum, Toxoplasma gondii, Trypanosoma cruzi, and Leishmania sp.

The parasitic disease with the greatest impact is malaria; it affects around $40 \%$ of the world's population, spanning across more than 100 countries, and its etiological agent is a protozoa belonging to the genus, Plasmodium [153]. Although different drugs can eliminate this parasite, the problem with the Plasmodium sp. is that its resistance needs to be overcome [154]; this indicates that the search for new antimalarial compounds is necessary and urgent.

In this regard, one of the first works to demonstrate the antimalarial properties of triterpenes against chloroquineresistant and chloroquine-sensitive Plasmodium falciparum was conducted by Steele et al. [155]. In this study, OA and UA were purified from ethanolic extract, which was prepared from the root barks of Uapaca nitida (Euphorbiaceae). UA showed antimalarial effects with an $\mathrm{IC}_{50}$ of $36.5 \mu \mathrm{g} / \mathrm{mL}$ and $28 \mu \mathrm{g} / \mathrm{mL}$ against chloroquine-resistant and chloroquinesensitive strains, respectively. Otherwise, the $\mathrm{IC}_{50}$ that was found for OA was $88.8 \mu \mathrm{g} / \mathrm{mL}$ and $70.6 \mu \mathrm{g} / \mathrm{mL}$ for chloroquine-resistant and chloroquine-sensitive strains, respectively. Other studies have also corroborated the potential of UA, purified from Mitragyna inermis, against chloroquinesensitive and chloroquine-resistant strains, showing an $\mathrm{IC}_{50}$ between $15 \mu \mathrm{g} / \mathrm{mL}$ and $18 \mu \mathrm{g} / \mathrm{mL}$. In addition, infected blood cells treated with UA presented with lower parasitism than did infected controls [94]. Other studies have also demonstrated that OA and UA purified from Satureia parvifolia, Mimusops caffra, M. obtusifolia, and Kleinia odora were able to eliminate P. falciparum [156-158].
Drugs based on pentavalent antimonials, Amphotericin $B$, nifurtimox, and benznidazole, are employed to treat patients with leishmaniasis and American trypanosomiasis but, unfortunately, these drugs are toxic and reports of parasite resistance to them have been constantly published, justifying the search for new active compounds. In infections caused by trypanosomatids, OA and UA were also tested, first in the use against Leishmania sp. parasites, and then against Trypanosoma cruzi, the etiological agents of leishmaniasis and American trypanosomiasis, respectively. Leishmaniasis is a complex disease, and its symptoms range from the presence of severe cutaneous lesions to the more visceral form of the disease, which affects the spleen, liver, and bone marrow [159].

Tan et al. [160] evaluated the leishmanicidal potential of OA and UA extracted from Salvia cilicica roots. The obtained results showed that UA was primarily active against intracellular amastigote forms of $L$. donovani and L. major, with an $\mathrm{IC}_{50}$ of $12.7 \mathrm{nM}$ and $7.0 \mathrm{nM}$, respectively. These values were comparable to the standard drug, Pentostam, whose $\mathrm{IC}_{50}$ was $10.6 \mathrm{nM}$ and $9.8 \mathrm{nM}$ against the same parasite species, respectively. $L$. (L.) amazonensis promastigotes were shown to be highly sensitive to OA and UA, presenting an $\mathrm{IC}_{50}$ of $10 \mu \mathrm{g} / \mathrm{mL}$ and $5 \mu \mathrm{g} / \mathrm{mL}$, respectively. In addition, both of these compounds were active against the intracellular form of L. (L.) amazonensis, showing an $\mathrm{IC}_{50}$ of $27 \mu \mathrm{g} / \mathrm{mL}$ and $11 \mu \mathrm{g} / \mathrm{mL}$, respectively. On the other hand, an $\mathrm{IC}_{50}$ of $83 \mu \mathrm{g} / \mathrm{mL}$ was obtained for experimental treatment with meglumine antimoniate [95], suggesting that these triterpenes are more effective than one of the standard drugs that is currently used to treat patients. The effect of these triterpenes on amastigote forms was not related to nitric oxide production, since elevation of this effector molecule was not verified in infected macrophages. Further studies also demonstrated that UA was active against promastigote forms of $L$. (L.) amazonensis, L. (L.) infantum [161], and L. (L.) donovani [162].

Recently, a bioguided study conducted with extracts of Baccharis uncinella leaves led to the identification of a bioactive fraction that contained OA and UA triterpenes. This fraction showed moderated activity against $L$. (V.) braziliensis and $L$. (L.) amazonensis promastigotes, although it was very active against amastigote forms of both parasite species; moreover, the leishmanicidal effect could be related to a direct effect on the amastigote forms. Additionally, these compounds triggered nitric oxide production in the macrophages, since infected cells incubated with the highest concentration of this fraction produced significant amounts of this effector molecule [26]. Due to this leishmanicidal potential, this fraction $(\mathrm{OA}+\mathrm{UA})$ was assayed as a prototype drug in $L$. (L.) amazonensis-infected mice. Animals that were treated with $1.0 \mathrm{mg} / \mathrm{kg}$ and $5.0 \mathrm{mg} / \mathrm{kg}$ of triterpene fraction presented with reduced lesion sizes and skin parasitism, which was accompanied by a significant elevation of IL-12 and interferon- (IFN-) $\gamma$ cytokines. Furthermore, the treatment did not alter the histological profile of the spleen, liver, heart, lungs, and kidneys of mice [27]. Interestingly, a total dose of $1.25 \mathrm{mg}$ of amphotericin B was required to eliminate $86 \%$ of parasites, while only $0.625 \mathrm{mg}$ of the triterpene fraction was required to inhibit approximately $93 \%$ of skin parasitism, 


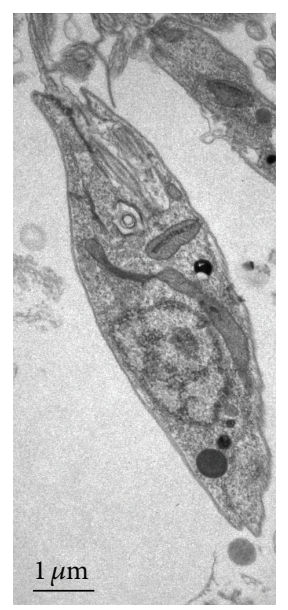

(a)

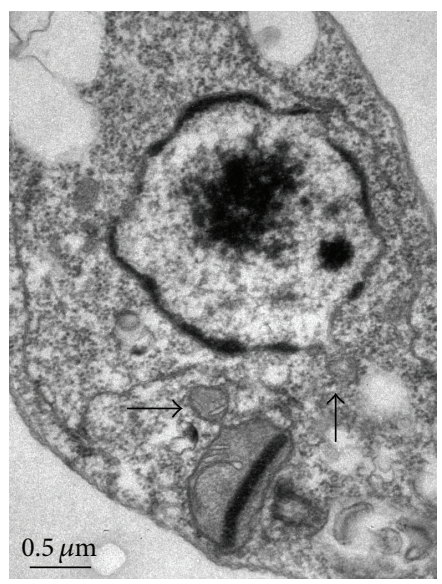

(c)

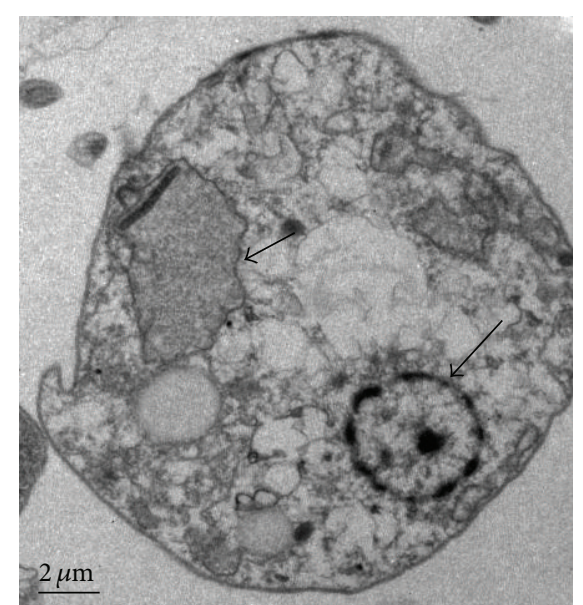

(b)

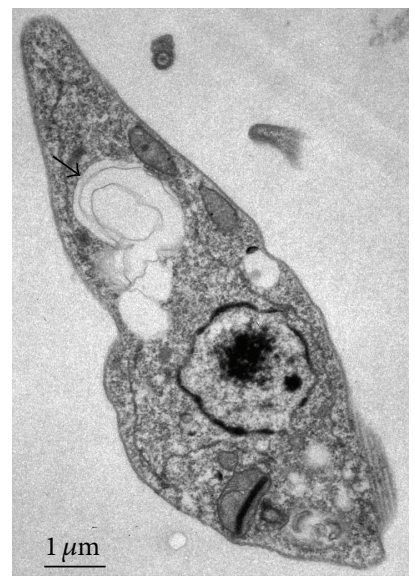

(d)

FIGURE 2: Ultrastructural alterations induced by $10.96 \mu \mathrm{g}$ of UA on promastigote forms of L. (L.) amazonensis. (a) Control parasites showed a normal morphology of the cell membranes, nucleus, and kinetoplast (20.000x). (b) Parasites treated with UA presented with evident external and internal alterations, such as mitochondrial swelling (arrowhead) and a pyknotic nucleus (short arrow) (10.000x); (c) Blebs (arrows) were detected in the nucleus and kinetoplast $(40.000 \mathrm{x})$; and (d) membranes were detected inside vacuoles, as indicated by the arrow (20.000x).

suggesting the elevated leishmanicidal potential of $\mathrm{OA}$ and UA.

In addition, our group demonstrated, through ultrastructural studies, that $L$. (L.) amazonensis promastigote forms treated with $10.96 \mu \mathrm{g}$ of UA presented with irreversible morphological changes after 18 hours of incubation. Control parasites presented with normal membrane morphology, cytoplasm, nucleus, mitochondrion, and flagellum (Figure 2(a)). Otherwise, treated parasites presented with rounded-shape morphology, and the intracellular environment presented with vacuoles, suggesting organelle degradation (Figure 2(b)) and swelling of the mitochondrion, and a pyknotic nucleus was detected (Figure 2(b)); blebs were also visualized in the nucleus and in the kinetoplast (Figure 2(c)). In addition, intracellular vacuoles presented with fragments of membranes (Figure 2(d)), suggesting degradation of the organelles. Taken together, these results suggest that, in promastigote forms of $L$. (L.) amazonensis, UA induces a mechanism of death associated to apoptosis or even autophagy.
This is the first study that depicted the possible mechanism of action of UA on $L$. (L.) amazonensis promastigote forms.

Based on previous works, these triterpenes can be regarded as antileishmanial agents since these studies demonstrated that these agents can be more effective than conventional drugs. In addition, more attention needs to be paid to UA, which is the primary antileishmanial agent when compared to its isomeric derivative, OA.

In American trypanosomiasis, the parasite T. cruzi infects a broad range of cell types, preferentially, muscle cells from the gut and heart, leading to a loss of organ function [163, 164]. Unfortunately, there are only two drugs that can be used to treat patients (nifurtimox and benznidazole), which are associated with serious side effects and are effective only in the acute phase of the disease [165], indicating that a search for a new trypanocidal compound is necessary. OA and UA purified from Miconia species were shown to be active against the blood form of T. cruzi; they showed an $\mathrm{IC}_{50}$ of $80.4 \mu \mathrm{M}$ and $21.3 \mu \mathrm{M}$, respectively, while the $\mathrm{IC}_{50}$ for gentamicin violet 
was $71.6 \mu \mathrm{M}$ [92], reinforcing the antiparasitic potential of UA. These interesting results led to the evaluation of the therapeutic potential of OA and UA triterpenes in a murine model of American trypanosomiasis. Animals treated with $2.0 \mathrm{mg} / \mathrm{kg}$ of OA, UA, and a mixture of OA plus UA presented with low parasitemia when compared to animals treated with benznidazole [166]. Ferreira et al. [167] also demonstrated that OA and UA were capable of controlling the peak of parasitemia in infected mice and, interestingly, treated mice did not show any alterations in their biochemical parameters, reinforcing the idea that these triterpenes are not toxic for animals. Considering the low or absent level of toxicity of triterpenes for mice, as well as their high trypanocidal activity, these results suggest that both compounds can be used for the development of new drugs against T. cruzi.

\section{Conclusion}

Several triterpenes, which displayed interesting structural features, have been considered inactive for a long period of time. However, different works have since demonstrated the wide array of pharmacological activities inherent in this class of natural compounds.

Specifically, UA and OA present remarkable antimicrobial activities, and they act against important human pathogens such as mycobacteria, HIV, and different protozoal species. The present review described interesting works about the antimicrobial action of UA and OA that, in fact, could be considered drug prototypes. In spite of this, the present review also alerted us to some concerns, insofar as the majority of the works presented here have not depicted the possible mechanism of action of these triterpenoids in microorganisms. Moreover, studies have not associated the in vitro potency of these agents with studies dealing with their therapeutic action (in vivo); this should be a priority in this field. In addition, these types of strategies will be crucial in the development of new drugs that can be used for populations that are at risk for contracting certain diseases.

\section{Conflict of Interests}

The authors declare that there is no conflict of interests regarding the publication of this paper.

\section{Acknowledgment}

The authors would like to thank the São Paulo Research Foundation for their support with Grants 2013/16297-2 and 2013/10133-8 and HCFMUSP-LIM50.

\section{References}

[1] E. Oldfield and F.-Y. Lin, "Terpene biosynthesis: modularity rules," Angewandte Chemie International Edition, vol. 51, no. 5, pp. 1124-1137, 2012.

[2] R. A. Hill and J. D. Connolly, "Triterpenoids," Natural Product Reports, vol. 29, no. 7, pp. 780-818, 2012.

[3] R. A. Hill and J. D. Connolly, "Triterpenoids," Natural Product Reports, vol. 28, no. 6, pp. 1087-1117, 2011.
[4] J. M. R. Patlolla and C. V. Rao, "Triterpenoids for cancer prevention and treatment: current status and future prospects," Current Pharmaceutical Biotechnology, vol. 13, no. 1, pp. 147-155, 2012.

[5] C. Cárdenas, A. R. Quesada, and M. Á. Medina, "Effects of ursolic acid on different steps of the angiogenic process," Biochemical and Biophysical Research Communications, vol. 320, no. 2, pp. 402-408, 2004.

[6] Z. Ovesná, A. Vachálková, K. Horváthová, and D. Tóthová, "Pentacyclic triterpenoic acids: new chemoprotective compounds. Minireview," Neoplasma, vol. 51, no. 5, pp. 327-333, 2004.

[7] T. Dorai and B. B. Aggarwal, "Role of chemopreventive agents in cancer therapy," Cancer Letters, vol. 215, no. 2, pp. 129-140, 2004.

[8] P. Zhang, H. Li, D. Chen, J. Ni, Y. Kang, and S. Wang, "Oleanolic acid induces apoptosis in human Leukemia cells through caspase activation and poly(ADP-ribose) polymerase cleavage," Acta Biochimica et Biophysica Sinica, vol. 39, no. 10, pp. 803-809, 2007.

[9] I. Bonaccorsi, F. Altieri, I. Sciamanna et al., "Endogenous reverse transcriptase as a mediator of ursolic acid's antiproliferative and differentiating effects in human cancer cell lines," Cancer Letters, vol. 263, no. 1, pp. 130-139, 2008.

[10] C. P. R. Xavier, C. F. Lima, A. Preto, R. Seruca, M. FernandesFerreira, and C. Pereira-Wilson, "Luteolin, quercetin and ursolic acid are potent inhibitors of proliferation and inducers of apoptosis in both KRAS and BRAF mutated human colorectal cancer cells," Cancer Letters, vol. 281, no. 2, pp. 162-170, 2009.

[11] A. Petronellia, G. Pannitterib, and U. Testaa, "Triterpenoids as new promising anticancer drugs," Anti-Cancer Drugs, vol. 20, no. 10 , pp. 880-892, 2009.

[12] J. Liu, "Pharmacology of oleanolic acid and ursolic acid," Journal of Ethnopharmacology, vol. 49, no. 2, pp. 57-68, 1995.

[13] K. Xu, F. Chu, G. Li et al., "Oleanolic acid synthetic oligoglycosides: a review on recent progress in biological activities," Pharmazie, vol. 69, no. 7, pp. 483-495, 2014.

[14] E. O. Fukushima, H. Seki, K. Ohyama et al., "CYP716A subfamily members are multifunctional oxidases in triterpenoid biosynthesis," Plant and Cell Physiology, vol. 52, no. 12, pp. 20502061, 2011.

[15] J. L. Simonsen and W. C. J. Ross, "Hydroxy acids, hydroxy lactones, hydroxyaldehydo acids, hydroxyketo acids and the stereochemistry of the triterpenes," in The Terpenes: The Triterpenes and Their Derivatives, Cambridge University Press, Cambridge, UK, 1957.

[16] M. B. Sporn, K. T. Liby, M. M. Yore, L. Fu, J. M. Lopchuk, and G. W. Gribble, "New synthetic triterpenoids: potent agents for prevention and treatment of tissue injury caused by inflammatory and oxidative stress," Journal of Natural Products, vol. 74, no. 3 , pp. 537-545, 2011.

[17] R. A. Heinzen, M. A. Scidmore, D. D. Rockey, and T. Hackstadt, "Differential interaction with endocytic and exocytic pathways distinguish parasitophorous vacuoles of Coxiella burnetii and Chlamydia trachomatis," Infection and Immunity, vol. 64, no. 3, pp. 796-809, 1996.

[18] A. Szakiel, A. Grzelak, P. Dudek, and W. Janiszowska, "Biosynthesis of oleanolic acid and its glycosides in Calendula officinalis suspension culture," Plant Physiology and Biochemistry, vol. 41, no. 3, pp. 271-275, 2003.

[19] L. T. K. Van, T. M. Hung, P. T. Thuong et al., "Oleananetype triterpenoids from Aceriphyllum rossii and their cytotoxic 
activity," Journal of Natural Products, vol. 72, no. 8, pp. 14191423, 2009.

[20] B.-S. Min, I. Lee, M.-J. Chang et al., "Anticomplementary activity of triterpenoids from the whole plant of Aceriphyllum rossii against the classical pathway," Planta Medica, vol. 74, no. 7, pp. 726-729, 2008.

[21] B. S. Min, "Anticomplementary activity of oleanane-type triterpenes from the roots of Aceriphyllum rossii," Archives of Pharmacal Research, vol. 35, no. 6, pp. 1003-1008, 2012.

[22] X.-F. Zhou, P. Zhang, H.-F. Pi et al., "Triterpenoids from the roots of Actinidia chinensis," Chemistry and Biodiversity, vol. 6, no. 8, pp. 1202-1207, 2009.

[23] B. Wang and Z. H. Jiang, "Studies on oleanolic acid," Chinese Pharmaceutical Journal, vol. 27, pp. 393-397, 1992.

[24] J. Liu, Y. P. Liu, and C. D. Klaassen, "The effect of Chinese hepatoprotective medicines on experimental liver injury in mice," Journal of Ethnopharmacology, vol. 42, no. 3, pp. 183-191, 1994.

[25] H.-X. Sun, Y.-P. Ye, and Y.-J. Pan, “Cytotoxic oleanane triterpenoids from the rhizomes of Astilbe chinensis (Maxim.) Franch. et Savat.," Journal of Ethnopharmacology, vol. 90, no. 23, pp. 261-265, 2004.

[26] L. F. D. Passero, A. Bonfim-Melo, C. E. P. Corbett et al., "Antileishmanial effects of purified compounds from aerial parts of Baccharis uncinella CDC (Asteraceae)," Parasitology Research, vol. 108, no. 3, pp. 529-536, 2011.

[27] E. S. Yamamoto, B. L. S. Campos, M. D. Laurenti et al., "Treatment with triterpenic fraction purified from Baccharis uncinella leaves inhibits Leishmania (Leishmania) amazonensis spreading and improves Th1 immune response in infected mice," Parasitology Research, vol. 113, no. 1, pp. 333-339, 2014.

[28] J.-Z. Deng, S. R. Starck, and S. M. Hecht, "DNA polymerase $\beta$ inhibitors from Baeckea gunniana," Journal of Natural Products, vol. 62, no. 12, pp. 1624-1626, 1999.

[29] T. Yabuchi, T. Tanaka, T. Sasatsuka, J. Yamahara, and H. Fujimura, "Extraction of oleanolic acid from sugar beets for treatment of liver failure," Chemical Abstracts, vol. 108, Article ID 82082, 1988.

[30] J. Liu, "Oleanolic acid and ursolic acid: research perspectives," Journal of Ethnopharmacology, vol. 49, pp. 57-68, 1995.

[31] C. Yamaguchi, Y. In, S.-I. Wada, T. Yamada, H. Tokuda, and R. Tanaka, "Cancer chemopreventive activity of oleanane-type triterpenoids from the stem bark of Betula ermanii," Chemistry and Biodiversity, vol. 6, no. 7, pp. 1093-1100, 2009.

[32] A. Favel, M. D. Steinmetz, P. Regli, E. Vidal-Ollivier, R. Elias, and G. Balansard, "In vitro antifungal activity of triterpenoid saponins," Planta Medica, vol. 60, no. 1, pp. 50-53, 1994.

[33] M.-Y. Lu, Z.-X. Liao, L.-J. Ji, and H.-F. Sun, "Triterpenoids of Chrysosplenium carnosum," Fitoterapia, vol. 85, no. 1, pp. 119124, 2013.

[34] T. T. Phuong, H. L. Chul, T. D. Trong et al., “Triterpenoids from the leaves of Diospyros kaki (Persimmon) and their inhibitory effects on protein tyrosine phosphatase 1B," Journal of Natural Products, vol. 71, no. 10, pp. 1775-1778, 2008.

[35] X.-F. He, X.-N. Wang, L.-S. Gan, S. Yin, L. Dong, and J.-M. Yue, "Two novel triterpenoids from Dysoxylum hainanense," Organic Letters, vol. 10, no. 19, pp. 4327-4330, 2008.

[36] M. K. Lee, H. Yang, J. S. Yoon et al., "Antifibrotic activity of diterpenes from Biota orientalis leaves on hepatic stellate cells," Archives of Pharmacal Research, vol. 31, no. 7, pp. 866-871, 2008.
[37] A. K. Machocho, P. C. Kiprono, S. Grinberg, and S. Bittner, "Pentacyclic triterpenoids from Embelia schimperi," Phytochemistry, vol. 62, no. 4, pp. 573-577, 2003.

[38] S. Balanehru and B. Nagarajan, "Protective effect of oleanolic acid and ursolic acid against lipid peroxidation," Biochemistry International, vol. 24, no. 5, pp. 981-990, 1991.

[39] S. Balanehru and B. Nagarajan, "Intervention of adriamycin induced free radical damage," Biochemistry International, vol. 28, no. 4, pp. 735-744, 1992.

[40] M. Rajasekaran, J. S. Bapna, S. Lakshmanan, A. G. R. Nair, A. J. Veliath, and M. Panchanadam, "Antifertility effect in male rats of oleanolic acid, a triterpene from Eugenia jambolana flowers," Journal of Ethnopharmacology, vol. 24, no. 1, pp. 115-121, 1988.

[41] Y.-C. Lai, C.-K. Chen, S.-F. Tsai, and S.-S. Lee, "Triterpenes as $\alpha$-glucosidase inhibitors from Fagus hayatae," Phytochemistry, vol. 74, pp. 206-211, 2012.

[42] S.-Y. Cheng, C.-M. Wang, Y.-M. Hsu et al., "Oleanane-type triterpenoids from the leaves and twigs of Fatsia polycarpa," Journal of Natural Products, vol. 74, no. 8, pp. 1744-1750, 2011.

[43] S. Hada, T. Hattori, and T. Namba, "Dental caries prevention by traditional medicines-effect of components of Ganoderma lucidum on ghrcosyltransferase from Streptococcusmutans," Chemical Abstracts, vol. 113, p. 91423, 1990.

[44] N. Yoshimi, A. Wang, Y. Morishita et al., "Modifying effects of fungal and herb metabolites on azoxymethane-induced intestinal carcinogenesis in rats," Japanese Journal of Cancer Research, vol. 83, no. 12, pp. 1273-1278, 1992.

[45] H. Ohigashi, H. Takamura, K. Koshimizu, H. Tokuda, and Y. Ito, "Search for possible antitumor promoters by inhibition of 12-O-tetradecanoylphorbol-13-acetate-induced Epstein-Barr virus activation; Ursolic acid and oleanolic acid from an antiinflammatory Chinese medicinal plant, Glechoma hederaceae L.", Cancer Letters, vol. 30, no. 2, pp. 143-151, 1986.

[46] H. Tokuda, H. Ohigashi, K. Koshimizu, and Y. Ito, "Inhibitory effects of ursolic and oleanolic ancid on skin tumor promotion by 12-O-tetradecanoylphorbol-13-acetate," Cancer Letters, vol. 33, no. 3, pp. 279-285, 1986.

[47] K. Nishimura, T. Fukuda, T. Miyase, H. Noguchi, and X.$\mathrm{M}$. Chen, "Activity-guided isolation of triterpenoid acyl CoA cholesteryl acyl transferase (ACAT) inhibitors from Ilex kudincha," Journal of Natural Products, vol. 62, no. 7, pp. 1061-1064, 1999.

[48] C. R. Pungitore, J. M. Padrón, L. G. Leon et al., "Inhibition of DNA topoisomerase I and growth inhibition of human cancer cell lines by an oleanane from Junellia aspera (Verbenaceae)," Cellular and Molecular Biology, vol. 53, no. 3, pp. 13-17, 2007.

[49] A. Jiménez-Arellanes, M. Meckes, J. Torres, and J. Luna-Herrera, "Antimycobacterial triterpenoids from Lantana hispida (Verbenaceae)," Journal of Ethnopharmacology, vol. 111, no. 2, pp. 202205, 2007.

[50] N. T. Dat, P. van Kiem, X. F. Cai, Q. Shen, K. Bae, and Y. H. Kim, "Gymnastone, a new benzofuran derivative from Gymnaster koraiensis," Archives of Pharmacal Research, vol. 27, no. 11, pp. 1106-1108, 2004.

[51] Y. Dai, B.-Q. Hang, Q.-Y. Meng, S.-P. Ma, and L.-W. Tan, "Inhibition of hypersensitivity reactions by oleanolic acid," Zhongguo Yao Li Xue Bao, vol. 9, no. 6, pp. 562-565, 1988.

[52] Y. Dai, B. Q. Hang, P. Z. Li, and L. W. Tan, "Effects of oleanolic acid on immune system and type I allergic reaction," Zhongguo Yao Li Xue Bao, vol. 10, no. 4, pp. 381-384, 1989. 
[53] J. Liu, Y. Liu, Q. Mao, and C. D. Klaassen, "The effects of 10 triterpenoid compounds on experimental liver injury in mice," Fundamental and Applied Toxicology, vol. 22, no. 1, pp. 34-40, 1994.

[54] M. Niikawa, H. Hayashi, T. Sato, H. Nagase, and H. Kito, "Isolation of substances from glossy privet (Ligustrum lucidum Ait.) inhibiting the mutagenicity of benzo[a]pyrene in bacteria," Mutation Research, vol. 319, no. 1, pp. 1-9, 1993.

[55] G. B. Singh, S. Singh, S. Bani, B. D. Gupta, and S. K. Banerjee, "Anti-inflammatory activity of oleanolic acid in rats and mice," Journal of Pharmacy and Pharmacology, vol. 44, no. 5, pp. 456458, 1992.

[56] A. Kapil and S. Sharma, "Anti-complement activity of oleanolic acid: an inhibitor of C3-convertase of the classical complement pathway," Journal of Pharmacy and Pharmacology, vol. 46, no. 11, pp. 922-923, 1994.

[57] X.-A. Huang, X.-L. Shen, Y.-J. Hu et al., “Two new triterpenoids from Lysimachia heterogenea klatt and evaluation of their cytotoxicity," Molecules, vol. 16, no. 9, pp. 8076-8082, 2011.

[58] Z. He, F. Liang, J. Lu, and Y. Pan, "Cytotoxic triterpenoids from Lysimachia parvifolia," European Journal of Medicinal Chemistry, vol. 67, pp. 390-397, 2013.

[59] M. Sánchez, M. Mazzuca, M. J. Veloso et al., "Cytotoxic terpenoids from Nardophyllum bryoides," Phytochemistry, vol. 71, no. 11-12, pp. 1395-1399, 2010.

[60] I.-H. Chen, M.-C. Lu, Y.-C. Du et al., "Cytotoxic triterpenoids from the stems of Microtropis japonica," Journal of Natural Products, vol. 72, no. 7, pp. 1231-1236, 2009.

[61] Z. Tian, Y.-M. Liu, S.-B. Chen et al., "Cytotoxicity of two triterpenoids from Nigella glandulifera," Molecules, vol. 11, no. 9, pp. 693-699, 2006.

[62] M. B. Gupta, T. N. Bhalla, G. P. Gupta, C. R. Mitra, and K. P. Bhargava, "Anti-inflammatory activity of natural products (I) Triterpenoids," European Journal of Pharmacology, vol. 6, no. 1, pp. 67-70, 1969.

[63] S. Shibata, "Saponins with biological and pharmacological activity," in New Natural Products And Plant Drugs with Pharmacologicalor Therapeutical Activity, H. Wagner and P. Wolff, Eds., Proceedings in Life Sciences, pp. 177-196, Springer, Berlin, Germany, 1977.

[64] C. Liang, Y. Ding, H. T. Nguyen et al., "Oleanane-type triterpenoids from Panax stipuleanatus and their anticancer activities," Bioorganic \& Medicinal Chemistry Letters, vol. 20, no. 23, pp. 7110-7115, 2010.

[65] C. Liang, Y. Ding, S. B. Song et al., "Oleanane-triterpenoids from Panax stipuleanatus inhibit NF- $\kappa \mathrm{B}$," Journal of Ginseng Research, vol. 37, no. 1, pp. 74-79, 2013.

[66] S.-I. Wada, A. Iida, and R. Tanaka, "Screening of triterpenoids isolated from Phyllanthus flexuosus for DNA topoisomerase inhibitory activity," Journal of Natural Products, vol. 64, no. 12, pp. 1545-1547, 2001.

[67] Q. Zhan, F. Zhang, L. Sun, Z. Wu, and W. Chen, "Two new oleanane-type triterpenoids from platycodi radix and antiproliferative activity in HSC-T6 Cells," Molecules, vol. 17, no. 12, pp. 14899-14907, 2012.

[68] N. Zeng, Y. Shen, L.-Z. Li et al., "Anti-inflammatory triterpenes from the leaves of Rosa laevigata," Journal of Natural Products, vol. 74, no. 4, pp. 732-738, 2011.

[69] M. Yan, Y. Zhu, H.-J. Zhang et al., "Anti-inflammatory secondary metabolites from the leaves of Rosa laevigata," Bioorganic \& Medicinal Chemistry, vol. 21, no. 11, pp. 3290-3297, 2013.
[70] K. Takagi, E. K. Park, and H. Kato, "Anti-inflammatory activities of hederagenin and crude saponin isolated from Sapindus mukorossi GAERTN," Chemical and Pharmaceutical Bulletin, vol. 28, no. 4, pp. 1183-1188, 1980.

[71] W. Kaweetripob, C. Mahidol, H. Prawat, and S. Ruchirawat, "Lupane, friedelane, oleanane, and ursane triterpenes from the stem of Siphonodon celastrineus Griff," Phytochemistry, vol. 96, pp. 404-417, 2013.

[72] C. Niampoka, R. Suttisri, R. Bavovada, H. Takayama, and N. Aimi, "Potentially cytotoxic triterpenoids from the root bark of Siphonodon celastrineus Griff," Archives of Pharmacal Research, vol. 28, no. 5, pp. 546-549, 2005.

[73] Hunan Med Inst, "Pharmacological studied of hepatoprotective compounds from Swertia mileensis," Traditional Medicine (Zhong Chao Yao), vol. 6, pp. 47-62, 1975.

[74] Human Medicine Institute, "Effects of oleanolic acid on experimental liver injury and therapeutic value in human hepatitis," Traditional Medicine, vol. 8, pp. 32-37, 1977.

[75] X. H. Ma, Y. C. Zhao, L. Yin, D. W. Han, and C. X. Ji, "Studies on the effect of oleanolic acid on experimental liver injury," Yao Xue Xue Bao, vol. 17, no. 2, pp. 93-97, 1982.

[76] H. Hikino, T. Ohsawa, Y. Kiso, and Y. Oshima, "Analgesic and antihepatotoxic actions of dianosides, triterpenoid saponins of Dianthus superbus var. longicalycinus Herbs," Planta Medica, vol. 50, no. 4, pp. 353-355, 1984.

[77] R. S. Pawar and K. K. Bhutani, "Effect of oleanane triterpenoids from Terminalia arjuna-a cardioprotective drug on the process of respiratory oxyburst," Phytomedicine, vol. 12, no. 5, pp. 391-393, 2005.

[78] A. Manosroi, P. Jantrawut, H. Akazawa, T. Akihisa, and J. Manosroi, "Biological activities of phenolic compounds isolated from galls of Terminalia chebula Retz. (Combretaceae)," Natural Product Research, vol. 24, no. 20, pp. 1915-1926, 2010.

[79] H. Hiroshi, K. Yoshinobu, A. Sakae, and O. Yukio, "Antihepatotoxic actions of papyriogenins and papyriosides, triterpenoids of Tetrapanax papyriferum leaves," Journal of Ethnopharmacology, vol. 12, no. 2, pp. 231-235, 1984.

[80] Z.Hao, B. Hang, and Y. Wang, "Hypoglycemic effect of oleanolic acid," Zhougguo Yaoke Daxue Xuebao, vol. 22, pp. 210-212, 1989.

[81] Z.-W. Wang, J.-S. Wang, J. Luo, and L.-Y. Kong, " $\alpha$-glucosidase inhibitory triterpenoids from the stem barks of Uncaria laevigata," Fitoterapia, vol. 90, pp. 30-37, 2013.

[82] M.-J. Zhang, B. Liu, S.-G. Liao et al., "Uncarilic acid and secouncarilic acid, two new triterpenoids from Uucaria sessilifructus," Molecules, vol. 18, no. 8, pp. 9727-9734, 2013.

[83] X.-Q. Chen, Y. Li, J. He et al., “Triterpenoids and diterpenoids from Viburnum chingii," Chemical and Pharmaceutical Bulletin, vol. 59, no. 4, pp. 496-498, 2011.

[84] M.-T. Huang, C.-T. Ho, Z. Y. Wang et al., "Inhibition of skin tumorigenesis by rosemary and its constituents carnosol and ursolic acid," Cancer Research, vol. 54, no. 3, pp. 701-708, 1994.

[85] M. Kondo, Phytochemical studies of extracts from cranberry (Vaccinium macrocarpon) with anti-cancer, anti-fungal and cardioprotective properties [M.S. thesis], University of Massachusetts Dartmouth, Dartmouth, Mass, USA, 2006.

[86] E. M. Varanda, G. E. Zúñiga, A. Salatino, N. F. Roque, and L. J. Corcuera, "Effect of ursolic acid from epicuticular waxes of Jacaranda decurrens on Schizaphis graminum," Journal of Natural Products, vol. 55, no. 6, pp. 800-803, 1992.

[87] J. D. Connolly and R. A. Hill, “Triterpenoids," Natural Product Reports, vol. 16, no. 2, pp. 221-240, 1999. 
[88] H. Safayhi and E.-R. Sailer, "Anti-inflammatory actions of pentacyclic triterpenes," Planta Medica, vol. 63, no. 6, pp. 487493, 1997.

[89] J.-L. Ríos, "Effects of triterpenes on the immune system," Journal of Ethnopharmacology, vol. 128, no. 1, pp. 1-14, 2010.

[90] I. Baglin, A. Poumaroux, M. Nour et al., "New ursolic and betulinic derivatives as potential cytotoxic agents," Journal of Enzyme Inhibition and Medicinal Chemistry, vol. 18, no. 2, pp. 111-117, 2003.

[91] I. Chinou, C. H. Liolios, D. Moreau, and C. H. Roussakis, "Cytotoxic activity of Origanum dictamnus," Fitoterapia, vol. 78, no. 5, pp. 342-344, 2007.

[92] W. R. Cunha, C. Martins, D. D. S. Ferreira, A. E. M. Crotti, N. P. Lopes, and S. Albuquerque, "In Vitro trypanocidal activity of triterpenes from Miconia species," Planta Medica, vol. 69, no. 5, pp. 470-472, 2003.

[93] A. T. C. Taketa, S. C. B. Gnoatto, G. Gosmann, V. S. Pires, E. P. Schenkel, and D. Guillaume, "Triterpenoids from Brazilian Ilex species and their in vitro antitrypanosomal activity," Journal of Natural Products, vol. 67, no. 10, pp. 1697-1700, 2004.

[94] F. Traore-Keita, M. Gasquet, C. di Giorgio et al., "Antimalarial activity of four plants used in traditional medicine in Mali," Phytotherapy Research, vol. 14, no. 1, pp. 45-47, 2000.

[95] E. C. Torres-Santos, D. Lopes, R. R. Oliveira et al., "Antileishmanial activity of isolated triterpenoids from Pourouma guianensis," Phytomedicine, vol. 11, no. 2-3, pp. 114-120, 2004.

[96] K. Kozai, Y. Miyake, H. Kohda et al., "Inhibition of glucosyltransferase from Streptococcus mutans by oleanolic acid and ursolic acid," Caries Research, vol. 21, no. 2, pp. 104-108, 1987.

[97] M. J. Kim, C. S. Kim, J. Y. Park et al., "Antimicrobial effects of ursolic acid against mutans Streptococci isolated from Koreans," International Journal of Oral Science, vol. 36, no. 1, pp. 7-11, 2011.

[98] A. Jiménez, M. Meckes, V. Alvarez, J. Torres, and R. Parra, "Secondary metabolites from Chamaedora tepejilote (Palmae) are active against Mycobacterium tuberculosis," Phytotherapy Research, vol. 19, no. 4, pp. 320-322, 2005.

[99] X.-F. Zhou, P. Zhang, H.-F. Pi et al., "Triterpenoids from the roots of Actinidia chinensis," Chemistry \& Biodiversity, vol. 6, no. 8, pp. 1202-1207, 2009.

[100] A. Simon, A. Najid, A. J. Chulia, C. Delage, and M. Rigaud, "Inhibition of lipoxygenase activity and HL60 leukemic cell proliferation by ursolic acid isolated from heather flowers (Calluna vulgaris)," Biochimica et Biophysica Acta (BBA)Lipids and Lipid Metabolism, vol. 1125, no. 1, pp. 68-72, 1992.

[101] A. Najid, A. Simon, J. Cook et al., "Characterization of ursolic acid as a lipoxygenase and cyclooxygenase inhibitor using macrophages, platelets and differentiated HL60 leukemic cells," FEBS Letters, vol. 299, no. 3, pp. 213-217, 1992.

[102] N. X. Nhiem, B. H. Tai, T. H. Quang et al., "A new ursane-type triterpenoid glycoside from Centella asiatica leaves modulates the production of nitric oxide and secretion of TNF- $\alpha$ in activated RAW 264.7 cells," Bioorganic \& Medicinal Chemistry Letters, vol. 21, no. 6, pp. 1777-1781, 2011.

[103] X.-D. Wu, J. He, X.-Y. Li et al., "Triterpenoids and steroids with cytotoxic activity from Emmenopterys henryi," Planta Medica, vol. 79, no. 14, pp. 1356-1361, 2013.

[104] H.-S. Young, H.-Y. Chung, C.-K. Lee, K.-Y. Park, T. Yokozawa, and H. Oura, "Ursolic acid inhibits aflatoxin $\mathrm{B}_{1}$-induced mutagenicity in a Salmonella assay system," Biological and Pharmaceutical Bulletin, vol. 17, no. 7, pp. 990-992, 1994.
[105] B. Shukla, P. K. S. Visen, G. K. Patnaik et al., "Hepatoprotective activity in the rat of ursolic acid isolated from Eucalyptus hybrid," Phytotherapy Research, vol. 6, no. 2, pp. 74-79, 1992.

[106] J. Sidana, S. Singh, S. K. Arora, W. J. Foley, and I. P. Singh, "Terpenoidal constituents of Eucalyptus loxophleba ssp. lissophloia," Pharmaceutical Biology, vol. 50, no. 7, pp. 823-827, 2012.

[107] N.-Y. Song, J.-G. Cho, D. Im et al., “Triterpenoids from Fragaria ananassa calyx and their inhibitory effects on melanogenesis in B16-F10 mouse melanoma cells," Natural Product Research: Formerly Natural Product Letters, vol. 27, no. 23, pp. 2219-2223, 2013.

[108] Q.-X. Wu, X. Liu, and Y.-P. Shi, "Chemical components from Gentiana aristata," Chemistry \& Biodiversity, vol. 4, no. 2, pp. 175-182, 2007.

[109] W.-L. Wang, X. Zhou, Y.-L. Liu, Q.-M. Xu, X.-R. Li, and S.-L. Yang, "Two new $20 \alpha(\mathrm{H})$-ursane-type triterpenoids from Ilex cornuta cornuta and their cytotoxic activities," Journal of Asian Natural Products Research, vol. 16, no. 2, pp. 175-180, 2014.

[110] M. S. Ali, S. A. Ibrahim, S. Jalil, and M. I. Choudhary, "Ursolic acid: a potent Inhibitor of superoxides produced in the cellular system," Phytotherapy Research, vol. 21, no. 6, pp. 558-561, 2007.

[111] T. Tsuruga, Y.-T. Chun, Y. Ebizuka, and U. Sankawa, "Biologically active constituents of Melaleuca leucadendron: inhibitors of induced histamine release from rat mast cells," Chemical and Pharmaceutical Bulletin, vol. 39, no. 12, pp. 3276-3278, 1991.

[112] X.-X. Wang, C.-J. Lin, and Z.-J. Jia, "Triterpenoids and sesquiterpenes from Mulgedium tataricum," Planta Medica, vol. 72, no. 8, pp. 764-767, 2006.

[113] J.-Y. Tao, S.-J. Dai, F. Zhao, J.-F. Liu, W.-S. Fang, and K. Liu, "New ursane-type triterpene with NO production suppressing activity from Nauclea officinalis," Journal of Asian Natural Products Research, vol. 14, no. 2, pp. 97-104, 2012.

[114] W.-D. Xie, Q. Zhang, P.-L. Li, and Z.-J. Jia, "Two triterpenoids and other constituents from Petasites tricholobus," Phytochemistry, vol. 66, no. 19, pp. 2340-2345, 2005.

[115] A. Choudhary, A. K. Mittal, M. Radhika et al., "Two new stereoisomeric antioxidant triterpenes from Potentilla fulgens," Fitoterapia, vol. 91, pp. 290-297, 2013.

[116] T. Kosuge, M. Yokota, K. Sugiyama, T. Mure, H. Yamazawa, and T. Yamamoto, "Studies on bioactive substances in crude drugs used for arthritic diseases in traditional Chinese medicine. III. Isolation and identification of anti-inflammatory and analgesic principles from the whole herb of Pyrola rotundifolia L," Chemical and Pharmaceutical Bulletin, vol. 33, no. 12, pp. 53555357, 1985.

[117] K.-H. Lee, Y.-M. Lin, T.-S. Wu et al., “The cytotoxic principles of Prunella vulgaris, Psychotria serpens, and Hyptis capitata: ursolic acid and related derivatives," Planta Medica, vol. 54, no. 4, pp. 308-311, 1988.

[118] Y. H. Choi, W. Zhou, J. Oh et al., "Rhododendric acid A, a new ursane-type PTP1B inhibitor from the endangered plant Rhododendron brachycarpum G. Don," Bioorganic and Medicinal Chemistry Letters, vol. 22, no. 19, pp. 6116-6119, 2012.

[119] M. A. Collins and H. P. Charles, "Antimicrobial activity of Carnosol and Ursolic acid: two anti-oxidant constituents of Rosmarinus officinalis L.", Food Microbiology, vol. 4, no. 4, pp. 311-315, 1987.

[120] K. Steinkamp-Fenske, L. Bollinger, N. Völler et al., "Ursolic acid from the Chinese herb danshen (Salvia miltiorrhiza L.) upregulates eNOS and downregulates Nox4 expression in human endothelial cells," Atherosclerosis, vol. 195, no. 1, pp. 104-111, 2007. 
[121] D. Zhang, W. Chen, X. Song, C. Han, Y. Wang, and G. Chen, "Three new ursane-type triterpenoids from the stems of Saprosma merrillii," Molecules, vol. 18, no. 12, pp. 14496-14504, 2013.

[122] C.-N. Lin, M.-I. Chung, and K.-H. Gan, "Novel antihepatotoxic principles of Solanum incanum," Planta Medica, vol. 54, no. 3, p. 222, 1988.

[123] I. L. Acebey-Castellon, L. Voutquenne-Nazabadioko, H. D. T. Mai et al., "Triterpenoid saponins from Symplocos lancifolia," Journal of Natural Products, vol. 74, no. 2, pp. 163-168, 2011.

[124] X. Hao, J. Zhang, G. Xia et al., "A new triterpenoid from Teucrium viscidum," Molecules, vol. 18, no. 1, pp. 1262-1269, 2013.

[125] K. H. Gan and C. N. Lin, "Studies on the constituents of Fonnosan gentianaceous plants XI-Constituents of Gentiana flavomaculata and Tripterospennum taiwanense and the antihepatotoxic activity of ursolic acid derivatives," Chinese Pharmceutical Journal, vol. 40, pp. 77-84, 1988.

[126] J.-J. Chen, D.-Q. Fei, S.-G. Chen, and K. Gao, "Antimicrobial triterpenoids from Vladimiria muliensis," Journal of Natural Products, vol. 71, no. 4, pp. 547-550, 2008.

[127] J. Lee, S.-T. Yee, J.-J. Kim et al., "Ursolic acid ameliorates thymic atrophy and hyperglycemia in streptozotocin-nicotinamideinduced diabetic mice," Chemico-Biological Interactions, vol. 188, no. 3, pp. 635-642, 2010.

[128] P. T. Thuong, B.-S. Min, W. Jin et al., "Anti-complementary activity of ursane-type triterpenoids from Weigela subsessilis," Biological and Pharmaceutical Bulletin, vol. 29, no. 4, pp. 830833, 2006.

[129] G. M. Woldemichael, S. G. Franzblau, F. Zhang, Y. Wang, and B. N. Timmermann, "Inhibitory effect of sterols from Ruprechtia triflora and diterpenes from Calceolaria pinnifolia on the growth of Mycobacterium tuberculosis," Planta Medica, vol. 69, no. 7, pp. 628-631, 2003.

[130] K. Horiuchi, S. Shiota, T. Hatano, T. Yoshida, T. Kuroda, and T. Tsuchiya, "Antimicrobial activity of oleanolic acid from Salvia officinalis and related compounds on vancomycin-resistant enterococci (VRE)," Biological \& Pharmaceutical Bulletin, vol. 30, no. 6, pp. 1147-1149, 2007.

[131] S. Fontanay, M. Grare, J. Mayer, C. Finance, and R. E. Duval, "Ursolic, oleanolic and betulinic acids: antibacterial spectra and selectivity indexes," Journal of Ethnopharmacology, vol. 120, no. 2, pp. 272-276, 2008.

[132] W. R. Cunha, G. X. de Matos, M. G. M. Souza et al., "Evaluation of the antibacterial activity of the methylene chloride extract of Miconia ligustroides, isolated triterpene acids, and ursolic acid derivatives," Pharmaceutical Biology, vol. 48, no. 2, pp. 166-169, 2010.

[133] A. Martins, A. Vasas, M. Viveiros, J. Molnár, J. Hohmann, and L. Amaral, "Antibacterial properties of compounds isolated from Carpobrotus edulis," International Journal of Antimicrobial Agents, vol. 37, no. 5, pp. 438-444, 2011.

[134] A. M. Grudniak, A. Kurek, J. Szarlak, and K. I. Wolska, "Oleanolic and ursolic acids influence affect the expression of the cysteine regulon and the stress response in Escherichia coli," Current Microbiology, vol. 62, no. 4, pp. 1331-1336, 2011.

[135] A. Kurek, A. M. Grudniak, M. Szwed et al., "Oleanolic acid and ursolic acid affect peptidoglycan metabolism in Listeria monocytogenes," Antonie van Leeuwenhoek, vol. 97, no. 1, pp. 6168, 2010.

[136] M. P. Girard, S. Osmanov, O. M. Assossou, and M.-P. Kieny, "Human immunodeficiency virus (HIV) immunopathogenesis and vaccine development: a review," Vaccine, vol. 29, no. 37, pp. 6191-6218, 2011.

[137] C. Ma, N. Nakamura, H. Miyashiro, M. Hattori, and K. Shimotohno, "Inhibitory effects of constituents from Cynomorium songaricum and related triterpene derivatives on HIV-1 protease," Chemical and Pharmaceutical Bulletin, vol. 47, no. 2, pp. 141-145, 1999.

[138] N. Nakamura, "Inhibitory effects of some traditional medicines on proliferation of HIV-1 and its protease," Yakugaku Zasshi, vol. 124, no. 8, pp. 519-529, 2004.

[139] J. R. Filho, H. D. S. Falcão, L. M. Batista, J. M. B. Filho, and M. R. Piuvezam, "Effects of plant extracts on HIV-1 protease," Current HIV Research, vol. 8, no. 7, pp. 531-544, 2010.

[140] F. Mengoni, M. Lichtner, L. Battinelli et al., "In vitro anti-HIV activity of oleanolic acid on infected human mononuclear cells," Planta Medica, vol. 68, no. 2, pp. 111-114, 2002.

[141] Y. Kashiwada, H. K. Wang, T. Nagao et al., "Anti-AIDS agentsanti-HIV activity of pomolic and structurally related triterpenoids," Journal Natural Products, vol. 61, no. 9, pp. 1090-1095, 1998.

[142] M. Hattori, C. M. Ma, Y. Wei, S. R. E. Dine, and N. Sato, "Survey of anti-HIV and anti-HCV compounds from Natural sources," Canadian Chemical Transactions, vol. 1, no. 2, pp. 116-140, 2013.

[143] M.-H. Shyu, T.-C. Kao, and G.-C. Yen, "Oleanolic acid and ursolic acid induce apoptosis in HuH7 human hepatocellular carcinoma cells through a mitochondrial-dependent pathway and downregulation of XIAP," Journal of Agricultural and Food Chemistry, vol. 58, no. 10, pp. 6110-6118, 2010.

[144] H.-Y. Wu, C.-I. Chang, B.-W. Lin et al., "Suppression of hepatitis B virus X protein-mediated tumorigenic effects by ursolic acid," Journal of Agricultural and Food Chemistry, vol. 59, no. 5, pp. 1713-1722, 2011.

[145] L. Kong, S. Li, Q. Liao et al., "Oleanolic acid and ursolic acid: novel hepatitis C virus antivirals that inhibit NS5B activity," Antiviral Research, vol. 98, no. 1, pp. 44-53, 2013.

[146] P. Bag, D. Chattopadhyay, H. Mukherjee et al., "Anti-herpes virus activities of bioactive fraction and isolated pure constituent of Mallotus peltatus: an ethnomedicine from Andaman Islands," Virology Journal, vol. 9, article 98, 2012.

[147] N. Bhargava, "Ethnobotanical studies of the tribes of Andaman and Nicobar Islands, India. I. Onge," Economic Botany, vol. 37, no. 1, pp. 110-119, 1983.

[148] B. R. Goyal, R. K. Goyal, and A. A. Mehta, "Phyto-pharmacology of Achyranthes aspera: a review," Pharmacognosy Reviews, vol. 1, no. 1, pp. 143-150, 2007.

[149] Y. Chen, Z. Zhu, Q. Guo, L. Zhang, and X. Zhang, "Variation in concentrations of major bioactive compounds in Prunella vulgaris L. related to plant parts and phenological stages," Biological Research, vol. 45, no. 2, pp. 171-175, 2012.

[150] H. Mukherjee, D. Ojha, P. Bag et al., "Anti-herpes virus activities of Achyranthes aspera: an Indian ethnomedicine, and its triterpene acid," Microbiological Research, vol. 168, no. 4, pp. 238-244, 2013.

[151] R. Nishikomori, S. Gurunathan, K. Nishikomori, and W. Strober, "BALB/c mice bearing a transgenic IL-12 receptor $\beta 2$ gene exhibit a nonhealing phenotype to Leishmania major infection despite intact IL-12 signaling," The Journal of Immunology, vol. 166, no. 11, pp. 6776-6783, 2001.

[152] L. F. D. Passero, M. L. A. D. C. Bordon, A. K. de Carvalho, L. M. Martins, C. E. P. Corbett, and M. D. Laurenti, "Exacerbation of Leishmania (Viannia) shawi infection in BALB/c mice after 
immunization with soluble antigen from amastigote forms," APMIS, vol. 118, no. 12, pp. 973-981, 2010.

[153] J. Oliveira-Ferreira, M. V. G. Lacerda, P. Brasil, J. L. B. Ladislau, P. L. Tauil, and C. T. Daniel-Ribeiro, "Malaria in Brazil: an overview," Malaria Journal, vol. 9, no. 1, article 115, 2010.

[154] C. H. Sibley and R. N. Price, "Monitoring antimalarial drug resistance: applying lessons learned from the past in a fastmoving present," International Journal for Parasitology: Drugs and Drug Resistance, vol. 2, pp. 126-133, 2012.

[155] J. C. P. Steele, D. C. Warhurst, G. C. Kirby, and M. S. J. Simmonds, "In vitro and in vivo evaluation of betulinic acid as an antimalarial," Phytotherapy Research, vol. 13, no. 2, pp. 115-119, 1999.

[156] C. van Baren, I. Anao, P. D. L. Lira et al., "Triterpenic acids and flavonoids from Satureja parvifolia, evaluation of their antiprotozoal activity," Journal of Biosciences, vol. 61, no. 3-4, pp. 189-192, 2006.

[157] M. B. C. Simelane, A. Shonhai, F. O. Shode, P. Smith, M. Singh, and A. R. Opoku, "Anti-plasmodial activity of some zulu medicinal plants and of some triterpenes isolated from them," Molecules, vol. 18, no. 10, pp. 12313-12323, 2013.

[158] N. M. Al Musayeib, R. A. Mothana, A. A. El Gamal, S. M. AlMassarani, and L. Maes, "In Vitro antiprotozoal activity of triterpenoid constituents of Kleinia odora growing in Saudi Arabia," Molecules, vol. 18, no. 8, pp. 9207-9218, 2013.

[159] B. S. McGwire and A. R. Satoskar, "Leishmaniasis: clinical syndromes and treatment," Quarterly Journal of Medicine, vol. 107, no. 1, pp. 7-14, 2013.

[160] N. Tan, M. Kaloga, O. A. Radtke et al., "Abietane diterpenoids and triterpenoic acids from Salvia cilicica and their antileishmanial activities," Phytochemistry, vol. 61, no. 8, pp. 881-884, 2002.

[161] S. C. B. Gnoatto, L. D. Vechia, C. L. Lencina et al., "Synthesis and preliminary evaluation of new ursolic and oleanolic acids derivatives as antileishmanial agents," Journal of Enzyme Inhibition and Medicinal Chemistry, vol. 23, no. 5, pp. 604-610, 2008.

[162] A. A. D. S. Filho, D. O. Resende, M. J. Fukui et al., "In vitro antileishmanial, antiplasmodial and cytotoxic activities of phenolics and triterpenoids from Baccharis dracunculifolia D. C. (Asteraceae)," Fitoterapia, vol. 80, no. 8, pp. 478-482, 2009.

[163] R. L. Tarleton, "Trypanosoma cruzi and chagas disease: cause and effect," in American Trypanosomiasis, vol. 7 of World Class Parasites, pp. 107-115, Springer, Berlin, Germany, 2003.

[164] P. Stahl, V. Ruppert, R. T. Schwarz, and T. Meyer, “Trypanosoma cruzi evades the protective role of interferon-gamma-signaling in parasite-infected cells," PLoS ONE, vol. 9, no. 10, Article ID e110512, 14 pages, 2014.

[165] J. R. Coura and S. L. de Castro, "A critical review on chagas disease chemotherapy," Memorias do Instituto Oswaldo Cruz, vol. 97, no. 1, pp. 3-24, 2002.

[166] W. R. Cunha, E. J. Crevelin, G. M. Arantes et al., "A study of the trypanocidal activity of triterpene acids isolated from Miconia species," Phytotherapy Research, vol. 20, no. 6, pp. 474-478, 2006.

[167] D. D. F. Ferreira, V. R. Esperandim, M. P. A. Toldo, J. Saraiva, W. R. Cunha, and S. de Albuquerque, "Trypanocidal activity and acute toxicity assessment of triterpene acids," Parasitology Research, vol. 106, no. 4, pp. 985-989, 2010. 


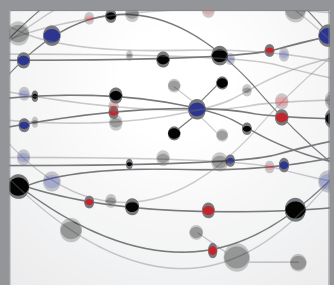

The Scientific World Journal
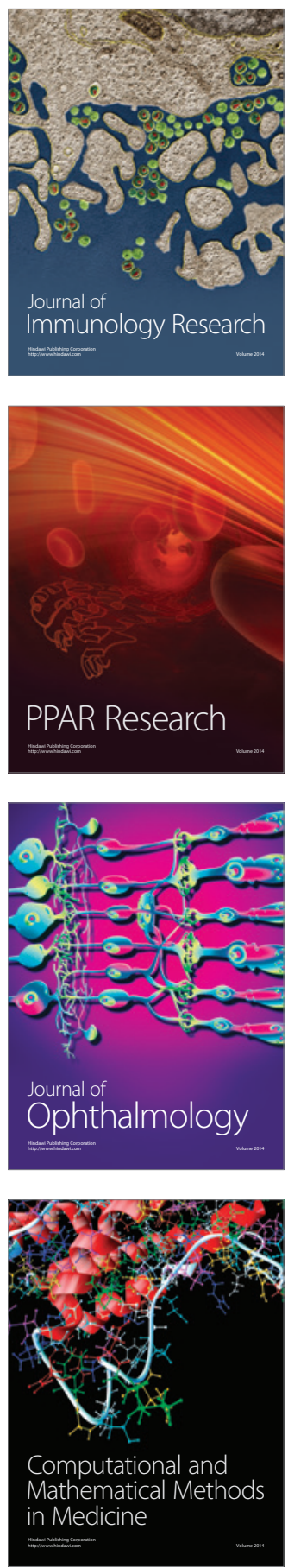

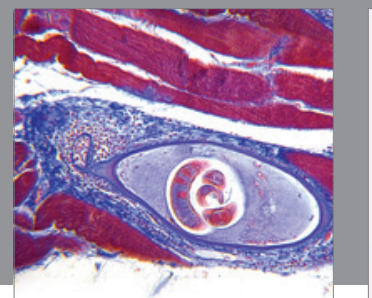

Gastroenterology

Research and Practice
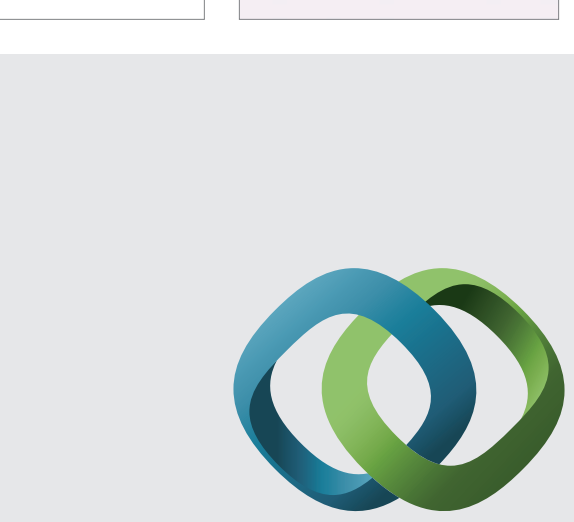

\section{Hindawi}

Submit your manuscripts at

http://www.hindawi.com
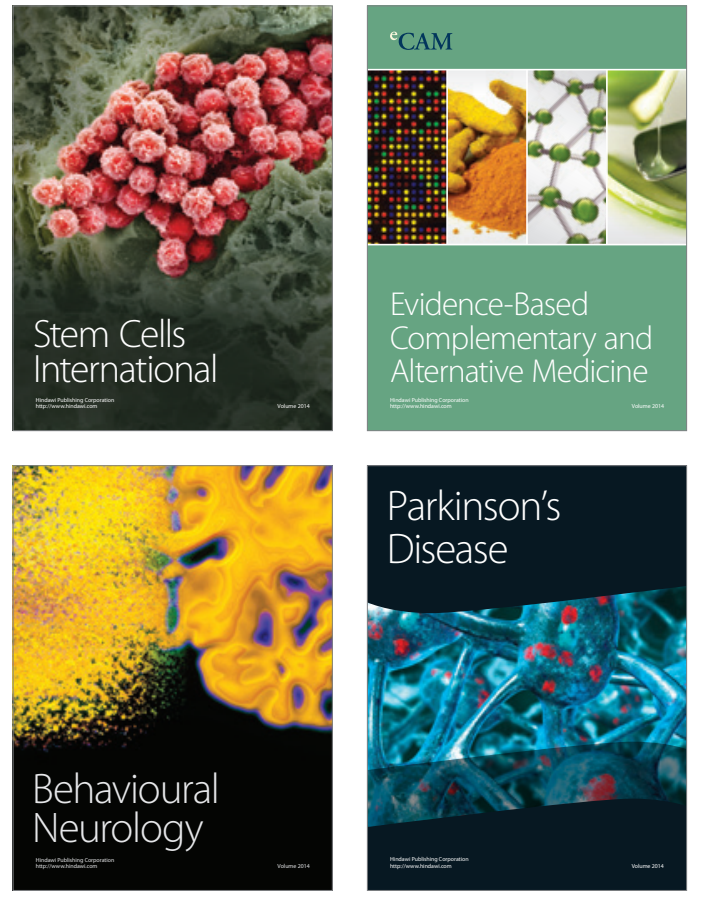
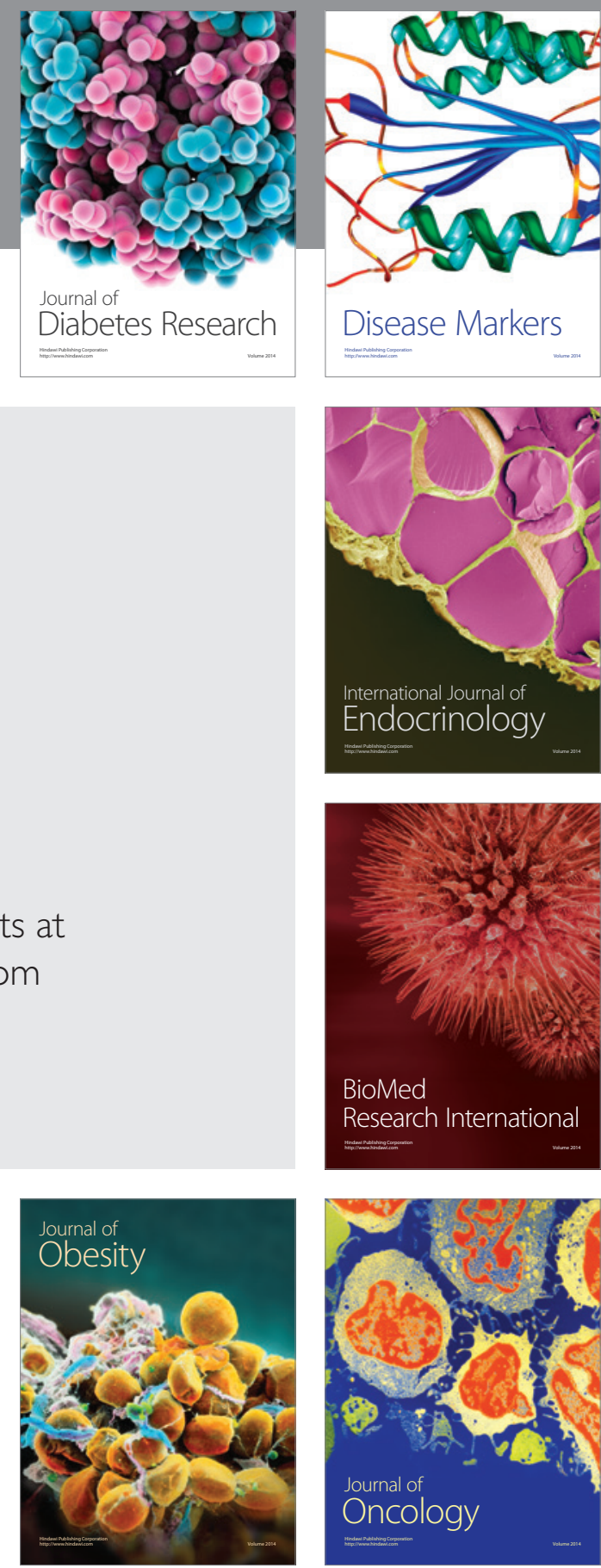

Disease Markers
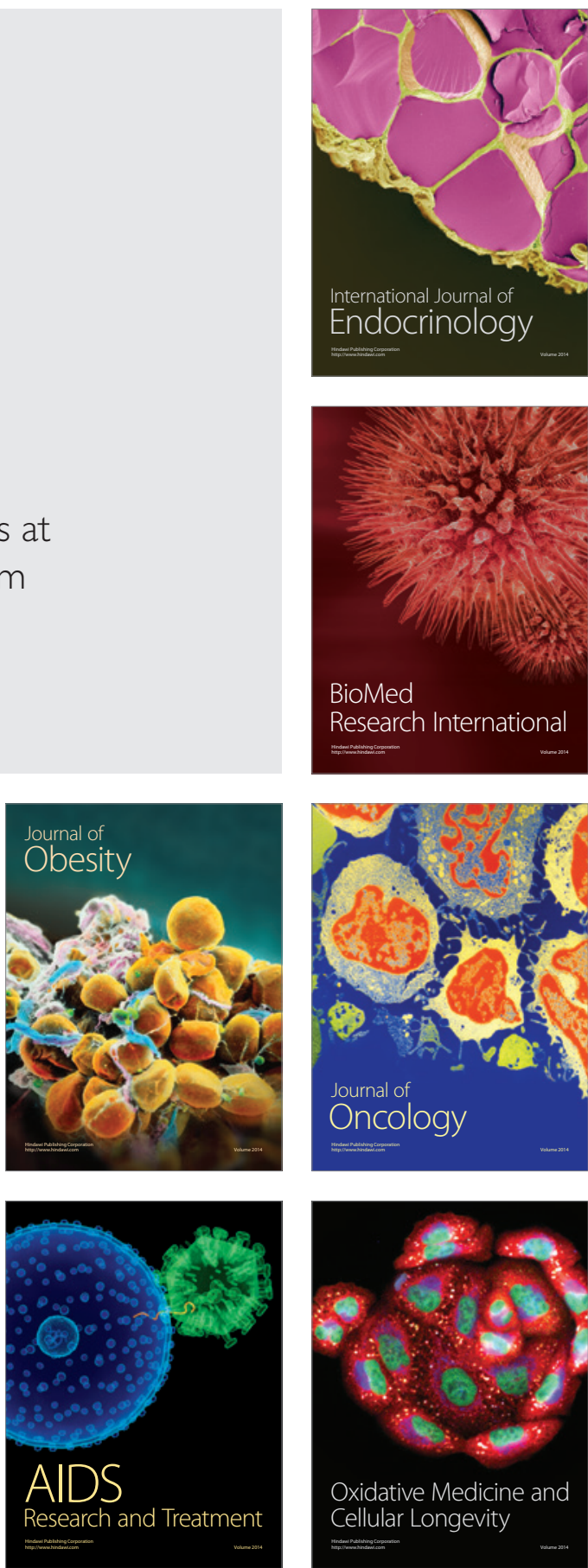